\title{
COMPARATIVE INFRARED SPECTROSCOPIC STUDY OF NATURAL CA-AMPHIBOLES
}

\section{Theodosoglou E. ${ }^{1}$, Koroneos A. ${ }^{1}$, Paraskevopoulos K. M. ${ }^{2}$, Christofides G. ${ }^{1}$, Papadopoulou L. ${ }^{1}$, and Zorba T. ${ }^{2}$}

${ }^{\prime}$ Aristotle University of Thessaloniki, School of Geology, Department of Mineralogy - Petrology Economic Geology,eltheod@geo.auth.gr,koroneos@geo.auth.gr,christof@geo.auth.gr, lambrini@geo.auth.gr

${ }^{2}$ Aristotle University of Thessaloniki, Physics Department, Solid State Physics Section, kpar@auth.gr,zorba@auth.gr

\begin{abstract}
Powder IR spectra of natural Ca-amphiboles were studied in the spectral range 4000 to $400 \mathrm{~cm}^{-1}$. The examined samples are: actinolite, tremolite, $\mathrm{Mg}$-hornblende and pargasite. According to their spectra all the minerals of the four species present common features at 3658-3660, 919, 683-687, 661-668, 505-513, 457-464 and 419 $\mathrm{cm}^{-1}$. Additionally to these bands, the spectra of the actinolites, tremolites and $\mathrm{Mg}$ hornblendes present common characteristics at 3673, 1094-1098, 989-998, 951, $752-758$ and 441-449 $\mathrm{cm}^{-1}$. Moreover, six absorption bands are shown in the spectra of the pargasites at 3690, 981-984, 931, 805-811, 734 and 696-698 $\mathrm{cm}^{-1}$, in addition to the common bands appeared in all Ca-amphiboles, which do not appear in the spectra of the actinolites, tremolites and Mg-hornblendes. The spectra of pargasites are remarkably different from the spectra of the other three mineral species. These discrepancies could be attributed to differences in the structure of pargasites relative to the other three species as well as to the occupancy of the A site especially with $\mathrm{Na}^{+}$.
\end{abstract}

Key words: FTIR, actinolite, tremolite, Mg-hornblende, pargasite.

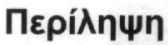

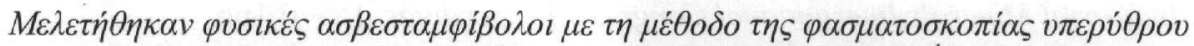

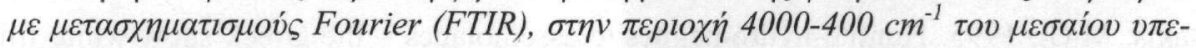

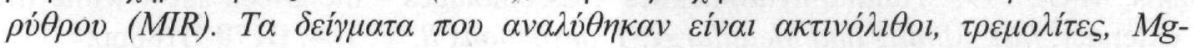

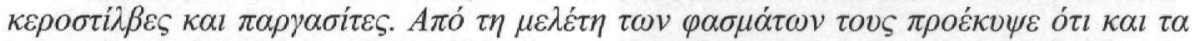

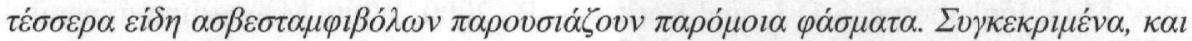

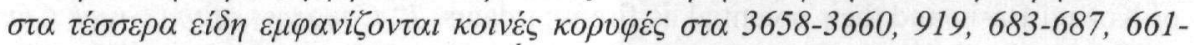

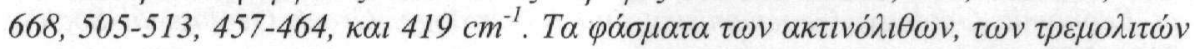

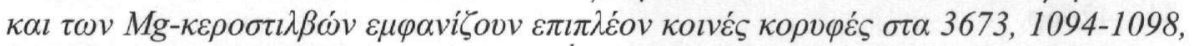

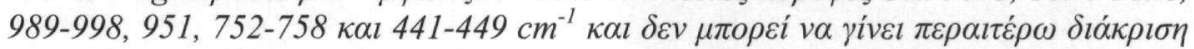

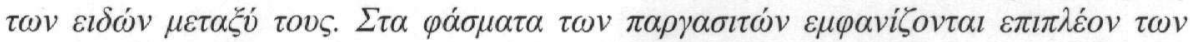

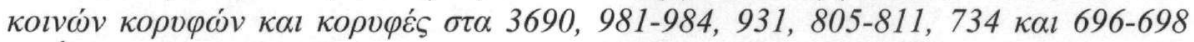

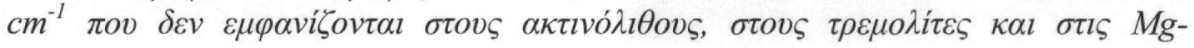




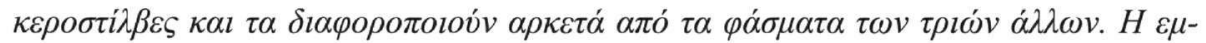


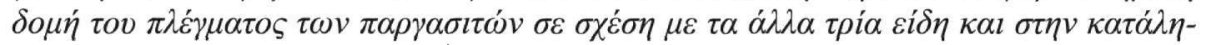

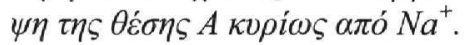

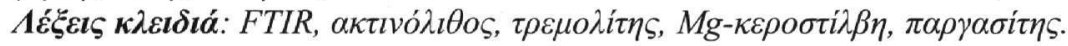

\section{Introduction}

Among the common methods usually used for the identification of minerals are the X-ray diffraction (XRD) method and the electron microprobe analysis (EMPA). FTIR analysis is, also, a useful method and FTIR spectra of synthetic and natural minerals have been obtained. However, although there are many FTIR studies, there is interest on the comparative examination of natural minerals, especially of minerals with complicated structures and formula units as the group of amphiboles, towards the identification of common characteristics. In this paper, natural Caamphiboles identified and classified by chemical microanalysis and X-ray diffraction techniques are investigated and characterized by FTIR spectra. The aim of the paper is the comparative study of natural Ca-amphiboles through their FTIR spectra as well as the attribution of characteristic bands to specific atomic groups and bond vibrations. The possibility to discriminate the species of the Ca-amphiboles on the basis of characteristic bands of their FTIR spectra is also examined.

\section{Materials and Methods}

\subsection{Samples}

The Ca-amphibole samples (Table 1) were collected mainly from the collections of the Mineralogy and Petrology Museum of the Aristotle University of Thessaloniki (A.U.Th.), while two samples $(\mathrm{H} 2$ and $\mathrm{H} 3$ ) from Xanthi plutonite were given by G. C. and correspond to the samples 250 and 117 respectively, of his Ph.D. thesis (Christofides, 1977).

Table 1 - Classification of the samples

\begin{tabular}{|c|l|l|l|}
\hline \multirow{2}{*}{ Sample } & \multicolumn{1}{|c|}{ Origin } & \multicolumn{2}{c|}{ Identification based on } \\
\cline { 3 - 4 } & \multicolumn{1}{|c|}{ XRPD } & Chemical composition \\
\hline A1 & Vertmont, France & Actinolite & Actinolite \\
\hline A2 & $\begin{array}{l}\text { Unknown, DeLaSalle College } \\
\text { Collection, Thessaloniki, Greece }\end{array}$ & Actinolite & Actinolite - Tremolite \\
\hline H1 & Skarn, Xanthi, Greece & Mg-hornblende & Mg-hornblende \\
\hline H2 & Granodiorite, Xanthi, Greece & Mg-hornblende & Mg-hornblende \\
\hline H3 & Monzogranite, Xanthi, Greece & Mg-hornblende & Mg-hornblende \\
\hline P1 & Marbles, Pargas, Finland & Pargasite & Pargasite \\
\hline P2 & Marbles, Pargas, Finland & Pargasite & Pargasite \\
\hline P3 & Marbles, Pargas, Finland & Pargasite & Pargasite \\
\hline T1 & Greiuer, Tirol, Austria & Tremolite (+Chlorite) & Tremolite \\
\hline T2 & Chester, Vertmont, U.S.A. & Tremolite (+Chlorite) & Tremolite \\
\hline T3 & Fahlun, Finland & Tremolite & Tremolite \\
\hline
\end{tabular}

\subsection{X-Ray Powder Diffraction (XRPD)}

Powder XRD patterns were obtained on a PHILIPS PW1820/00 X-ray diffractometer of the Department of Mineralogy - Petrology - Economic Geology, School of Geology, A.U.Th., carrying a 
PW1710 microprocessor and using the PC-APD software. Operating conditions for all samples were $35 \mathrm{kV}$ and $25 \mathrm{~mA}$ using Ni-filtered $\mathrm{CuK}_{\text {aave }}$ radiation. The 2 theta $(2 \theta)$ scanning range was between $3^{\circ}$ and $63^{\circ}$ and the scanning speed was $1.2^{\circ} / \mathrm{min}$. Silicon was used as external standard. The identification of the samples was made with the JCPDS-ICDD 2003 database.

\subsection{Electron Microprobe Analysis (EMPA)}

Electron Microprobe Analysis was carried out in the Scanning Microscope Laboratory, A.U.Th., using a JEOL JSM-840A Scanning Electron Microscope (SEM) equipped with an Energy Dispersive Spectrometer (EDS) with $20 \mathrm{kV}$ accelerating voltage and $0.4 \mathrm{~mA}$ probe current. Pure Co was used as an optimization element. Line analyses from the center of the crystal towards the rim were performed. The chemical composition of each sample represents mean values of five to eight spots.

\subsection{Fourier Transform Infrared Spectroscopy (FTIR)}

Powdered samples were prepared by grinding about $10 \mathrm{mg}$ of sample in an agate mortar with acetone, to avoid oxidizing the $\mathrm{Fe}^{2+}$, until the grain size was generally less than $20 \mu \mathrm{m}$. After drying to evaporate the acetone, $2.5 \mathrm{mg}$ of Ca-amphibole was homogenized with $250 \mathrm{mg}$ of $\mathrm{KBr}$ by grinding in an agate mortar. The mixture was pressed at $7 \mathrm{tn}$ for $5 \mathrm{~min}$ using a hydraulic hand press in an evacuated die into a $13 \mathrm{~mm}$ pellet. The pellets were dried at $110{ }^{\circ} \mathrm{C}$ for 2 hours before the collection of the spectra.

The infrared spectra of the samples were recorded in the region of mid IR (MIR, 4000 to $400 \mathrm{~cm}^{-1}$ ) with mean average of 32 scans and resolution $4 \mathrm{~cm}^{-1}$ on a PERKIN-ELMER FTIR Spectrum 1000 Spectrometer of the Solid State Physics Section, Physics Department, A.U.Th. A pure KBr pellet was used as reference.

\section{Results}

\subsection{General}

The XRPD patterns of four representative samples are presented in Figure 1 while the identification of all samples based on the patterns is presented in Table 1. According to the patterns, the samples are divided in four species: actinolites (A1 and A2), tremolites (T1, T2 and T3), Mg-hornblendes ( $\mathrm{H} 1, \mathrm{H} 2$ and H3) and pargasites (P1, P2 and P3). It must be noted that in the $\mathrm{T} 1$ and T2 sample patterns a quite large amount of chlorite is observed.

The results of microanalysis of the samples are presented in Table 2 . The calculation of the chemical formulae and the $\mathrm{Fe}^{3+} / \mathrm{Fe}^{2+}$ estimation were based on the method proposed by Leake et al . (1997, appendix 2). The Ca cations in B site are $\geq 1.5$ atoms per formula unit (apfu) in all samples, and according to Leake et al. $(1997,2003)$ they belong to the Ca-amphibole group. The samples with $\mathrm{Na}$ and $\mathrm{K}$ in A site $\leq 0.5$ apfu are plotted on Figure 2a (Leake et al. 1997, 2003) in the fields of actinolite (A1 and A2), Mg-hornblende (H1, H2 and H3) and tremolite (T1, T2 and T3). The samples with $\mathrm{Na}$ and $\mathrm{K}$ in A site $\geq 0.5$ apfu are plotted on Figure $2 \mathrm{~b}$ (Leake et al. 1997, 2003) in the field of pargasite (P1, P2 and P3), (Table 1). The nomenclature of the samples, based on the chemical analyses, is in agreement with their identification by the XRPD method. The $\mathrm{Mg} /\left(\mathrm{Mg}+\mathrm{Fe}^{2+}\right)$ ratio is relatively high in all samples and ranges between 0.78 and 1.00 (except $\mathrm{H} 2$ sample where it is 0.72 ). Concerning the concentrations of $\mathrm{Si}$ and $\mathrm{Al}$, they are quite different among the samples. Specifically, in actinolites, tremolites and $\mathrm{Mg}$-hornblendes the concentration of Si ranges between 7.17 and 7.93 apfu and the concentration of $\mathrm{Al}$ ranges from 0.14 to 0.99 apfu.

In pargasites the concentration of $\mathrm{Si}$ is lower than that of the other three species, ranging between 6.22 and 6.49 apfu while the concentration of $\mathrm{Al}$ is higher and ranges from 1.97 to 2.34 apfu.

In the FTIR spectra of the investigated samples (Fig. 3) two regions can be distinguished: 
1. The region between 400 and $1600 \mathrm{~cm}^{-1}$ (Fig. 4) where bands are attributed to the vibrations of $\mathrm{Si}$ and $\mathrm{Al}$ bonds with $\mathrm{O}$ in the structure of the minerals ( $\mathrm{Si}-\mathrm{O}, \mathrm{Si}-\mathrm{O}-\mathrm{Si}, \mathrm{Si}-\mathrm{O}-\mathrm{Al}$, etc.).

2. The region between 3200 and $4000 \mathrm{~cm}^{-1}$ (Fig. 5) where bands are attributed to the stretching vibrations of $\mathrm{OH}^{-}$groups coordinated by M1 and M3 cations (Farmer 1974).

In the region between 2300 and $2400 \mathrm{~cm}^{-1}$ the weak bands are attributed to the atmospheric $\mathrm{CO}_{2}$ in the sample chamber.
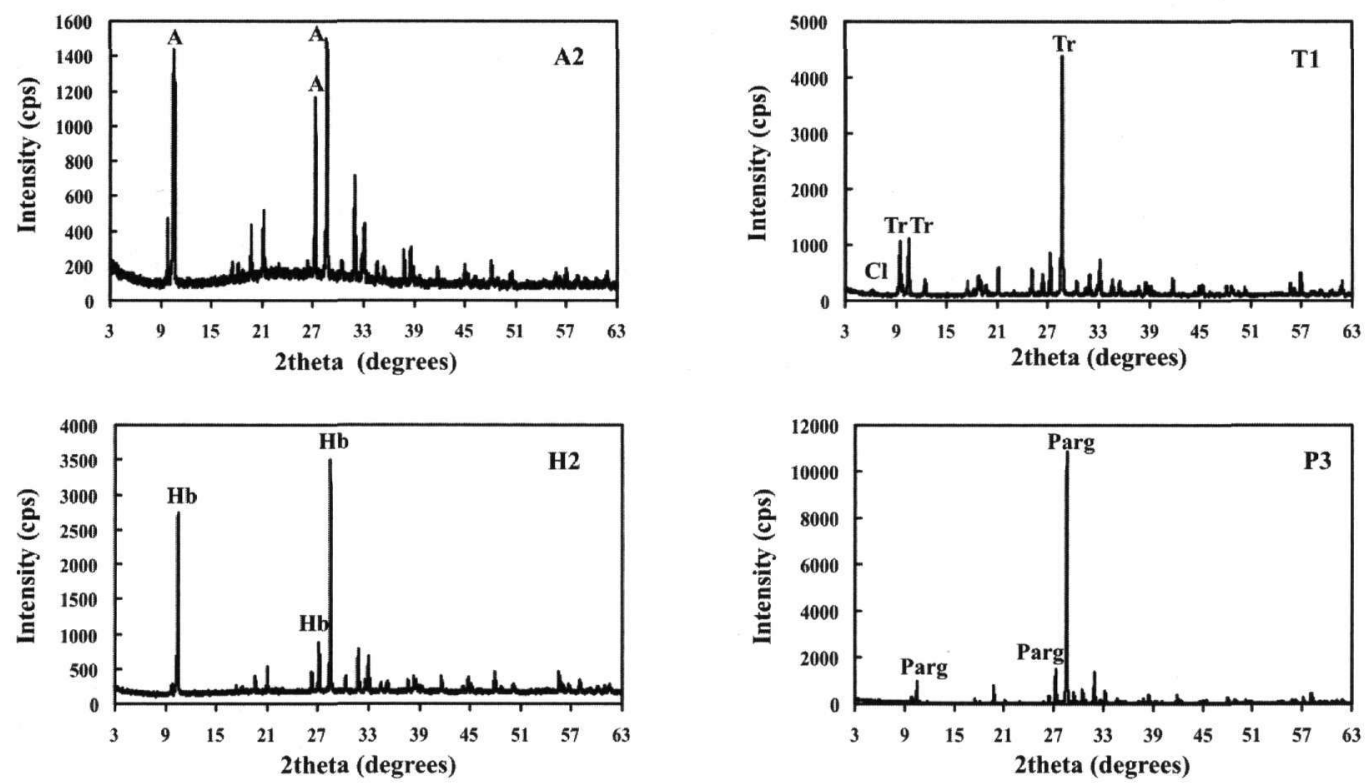

Figure 1 - XRPD pattern of representative samples (A: actinolite, Parg: pargasite, $\mathrm{Hb}$ : $\mathrm{Mg}$ hornblende, Tr: tremolite, $\mathrm{Cl}$ : chlorite)

\subsection{Actinolites, Tremolites, Mg-Hornblendes}

\subsubsection{Low frequency region: $400-1600 \mathrm{~cm}^{-1}$}

The spectra of these minerals are presented in Figures 3a to c and 4a to c. Generally, in all mineral spectra it can be seen that around $1000 \mathrm{~cm}^{-1}$ appear absorption bands, which are ascribed to stretching vibrations of the T-O bonds, while below $600 \mathrm{~cm}^{-1}$, absorption bands appear, due to the bending vibrations of T-O-T bonds. The sharp band at $459 \mathrm{~cm}^{-1}$ is attributed to Si-O bending (Gopal et al. 2004) while the band at $668 \mathrm{~cm}^{-1}$ to small amounts of $\mathrm{Fe}^{2+}$ in the amphibole structure (Hawthorne 1981, Carmichael 1982, Prasad et al. 2000). According to Gopal et al. (2004) the bands at 685 and $757 \mathrm{~cm}^{-1}$ are attributed to symmetrical stretching of Si-O-Si bonding. Lucania et al. (2002) supported that the bands at 919 and $951 \mathrm{~cm}^{-1}$ are characteristic in natural actinolites, while Prasad et al. (2000) reported that these absorption bands are characteristic in the spectra of natural tremolites. All the above mentioned absorption bands are common in all the investigated samples of actinolites, tremolites and Mg-hornblendes. Although the samples are classified in three different species of Ca-amphiboles, they have small differences in their chemical composition (Table 2, Figs 2a, b). The band at about $951 \mathrm{~cm}^{-1}$, corresponding to the $955 \mathrm{~cm}^{-1}$ of Gopal et al. (2004), can be attributed to the symmetric in-plane stretching vibration of the Si-O bond. This bond existing in all amphiboles is observed in the spectra of all samples. The band at $1094-1098 \mathrm{~cm}^{-1}$ is reported by Prasad et al. (2000) and according to Gopal et al. (2004) this band is ascribed to antisymmetrical stretching vibration of $\mathrm{Si}-\mathrm{O}-\mathrm{Si}$ bond. Furthermore, there are four more absorption bands at 989-998, 505-513, 441-449 and $419 \mathrm{~cm}^{-1}$ in the spectra of the actinolites, tremolites and Mg-hornblendes which can not be related with specific bond vibrations according to 
the existing literature. All the above mentioned absorption bands are common in all the investigated samples of actinolites, tremolites and Mg-hornblendes.

Table 2 - Chemical analyses of the samples

\begin{tabular}{|c|c|c|c|c|c|c|c|c|c|c|c|}
\hline & P1 & $\overline{\mathbf{P 2}}$ & P3 & H1 & H2 & H3 & $\overline{A 1}$ & $\overline{\mathbf{A 2}}$ & T1 & T2 & T3 \\
\hline $\mathrm{SiO}_{2}$ & 44.82 & 43.88 & 46.78 & 52.34 & 49,36 & 51.94 & 53.59 & 56.24 & 57.24 & 56.19 & 57.49 \\
\hline $\mathrm{TiO}_{2}$ & 0.06 & 0.57 & 0.00 & 0.20 & 0,76 & 0.67 & 0.22 & 0.11 & 0.06 & 0.00 & 0.06 \\
\hline $\mathbf{A l}_{2} \mathbf{O}_{3}$ & 14.07 & 13.66 & 12.07 & 5.98 & 4,87 & 4.20 & 4.78 & 2.80 & 1.19 & 1.05 & 0.87 \\
\hline $\mathrm{FeO}_{\mathrm{t}}$ & 3.04 & 4.73 & 1.30 & 6.19 & 13,68 & 11.22 & 8.67 & 5.81 & 3.48 & 4.18 & 3.38 \\
\hline $\mathrm{MnO}$ & 0.03 & 0.09 & 0.06 & 0.26 & 0,56 & 0.83 & 0.14 & 0.17 & 0.19 & 0.36 & 0.45 \\
\hline MgO & 19.49 & 18.95 & 21.82 & 19.76 & 15,05 & 16.44 & 17.64 & 21.13 & 24.10 & 22.10 & 23.17 \\
\hline $\mathrm{CaO}$ & 12.01 & 11.20 & 11.97 & 10.88 & 12,35 & 11.03 & 11.68 & 10.86 & 11.06 & 10.91 & 11.54 \\
\hline $\mathrm{Na}_{2} \mathrm{O}$ & 3.27 & 3.42 & 3.34 & 1.23 & 0,84 & 1.03 & 0.88 & 0.86 & 0.48 & 0.26 & 0.16 \\
\hline $\mathrm{K}_{2} \mathrm{O}$ & 0.68 & 0.79 & 1.08 & 0.10 & 0,31 & 0.30 & 0.14 & 0.10 & 0.00 & 0.00 & 0.00 \\
\hline Total & 97,47 & 97,29 & 98,42 & 96,94 & 97,78 & 97,66 & 97,74 & 98,08 & 97,80 & 95,05 & 97,12 \\
\hline \multicolumn{12}{|c|}{ Structural formula based on 230} \\
\hline Si & 6.312 & 6.224 & 6.488 & 7.313 & 7,169 & 7.417 & 7.527 & 7.737 & 7.823 & 7.928 & 7.918 \\
\hline $\mathrm{Al}^{\mathrm{IV}}$ & 1.688 & 1.776 & 1.512 & 0.687 & 0,831 & 0.583 & 0.473 & 0.263 & 0.177 & 0.072 & 0.082 \\
\hline$T$ & 8.000 & 8.000 & 8.000 & 8.000 & 8,000 & 8.000 & 8.000 & 8.000 & 8.000 & 8.000 & 8.000 \\
\hline $\mathrm{Al}^{\mathrm{VI}}$ & 0.648 & 0.507 & 0.462 & 0.298 & 0,002 & 0.124 & 0.319 & 0.191 & 0.015 & 0.103 & 0.060 \\
\hline $\mathbf{T i}$ & 0.006 & 0.061 & 0.000 & 0.021 & 0,083 & 0.072 & 0.023 & 0.011 & 0.006 & 0.000 & 0.006 \\
\hline $\mathrm{Fe}^{3+}$ & 0.178 & 0.365 & 0.144 & 0.359 & 0,378 & 0.328 & 0.194 & 0.158 & 0.085 & 0.024 & 0.031 \\
\hline $\mathrm{Mg}$ & 4.090 & 4.007 & 4.394 & 4.116 & 3,258 & 3.499 & 3.692 & 4.333 & 4.894 & 4.649 & 4.758 \\
\hline $\mathrm{Fe}^{2+}$ & 0.078 & 0.060 & 0.000 & 0.206 & 1,279 & 0.977 & 0.772 & 0.307 & 0.000 & 0.224 & 0.145 \\
\hline$C$ & 5.000 & 5.000 & 5.000 & 5.000 & 5,000 & 5.000 & 5.000 & 5.000 & 5.000 & 5.000 & 5.000 \\
\hline $\mathrm{Mg}$ & 0.000 & 0.000 & 0.117 & 0.000 & 0,000 & 0.000 & 0.000 & 0.000 & 0.016 & 0.000 & 0.000 \\
\hline $\mathrm{Fe}^{2+}$ & 0.102 & 0.136 & 0.006 & 0.159 & 0,005 & 0.036 & 0.052 & 0.203 & 0.312 & 0.245 & 0.214 \\
\hline Mn & 0.004 & 0.011 & 0.006 & 0.031 & 0,069 & 0.101 & 0.016 & 0.020 & 0.022 & 0.043 & 0.052 \\
\hline $\mathrm{Ca}$ & 1.812 & 1.703 & 1.779 & 1.629 & 1,922 & 1.687 & 1.757 & 1.600 & 1.619 & 1.649 & 1.702 \\
\hline $\mathrm{Na}$ & 0.082 & 0.150 & 0.092 & 0.181 & 0,004 & 0.176 & 0.175 & 0.177 & 0.031 & 0.063 & 0.032 \\
\hline$B$ & 2.000 & 2.000 & 2.000 & 2.000 & 2,000 & 2.000 & 2.000 & 2.000 & 2.000 & 2.000 & 2.000 \\
\hline $\mathrm{Na}$ & 0.811 & 0.790 & 0.807 & 0.152 & 0,232 & 0.109 & 0.064 & 0.052 & 0.095 & 0.008 & 0.010 \\
\hline $\mathbf{K}$ & 0.122 & 0.143 & 0.191 & 0.018 & 0.057 & 0.055 & 0.025 & 0.018 & 0.000 & 0.000 & 0.001 \\
\hline$A$ & 0.933 & 0.933 & 0.998 & 0.170 & 0.289 & 0.164 & 0.089 & 0.070 & 0.095 & 0.008 & 0.011 \\
\hline
\end{tabular}

\subsubsection{OH absorption region}

In the region with wavenumber between 3200 and $4000 \mathrm{~cm}^{-1}$, the $\mathrm{OH}$ area (Figs $5 \mathrm{a}-\mathrm{c}$ ), the OHmetal ion bonds are present. In the amphibole structure, the $\mathrm{OH}$ group is bonded to two M1 and one M3 cations and the $\mathrm{H}$ atom projects into the A site cavity, which can be vacant or occupied (Della Ventura et al. 1999, Hawthorne et al. 2000, Della Ventura et al. 2003). The small band at $3658-3660 \mathrm{~cm}^{-1}$ is attributed to the presence of $\mathrm{Mg}$ in the M1 sites and $\mathrm{Fe}^{2+}$ in the M3 site (Burns and Strens 1966, Burns and Greaves 1971). The sharp band at $3673 \mathrm{~cm}^{-1}$ is attributed to the presence of Mg in the M1 and M3 sites (Burns and Strens 1966, Burns and Greaves 1971, Hawthorne et al. 2000, Jenkins et al. 2003). A weak band at $3641 \mathrm{~cm}^{-1}$ observed only in the spectra of $\mathrm{H} 2$ and $\mathrm{H} 3$ samples is attributed to the presence of $\mathrm{MgFe}^{2+} \mathrm{Fe}^{2+}$ in the M1M1M3 sites (Burns and Strens 1966, Burns and Greaves 1971). This observation is also confirmed from the chemical analysis where the amount of $\mathrm{FeO}_{\mathrm{t}}$ is higher than the amount of the rest samples.

It must be noticed here that the co-existence of chlorite in the samples T1 and T2 (Fig. 1), identified by XRPD, is also confirmed from their FTIR spectra. Although in the low frequency region 
the absorption bands of chlorite (at $991,824,756,664$ and $446 \mathrm{~cm}^{-1}$ ) are overlapped by the absorption bands of tremolite, in the $\mathrm{OH}$ absorption region its presence is recognized from a broad double absorption band at $3420-3430$ and $3571 \mathrm{~cm}^{-1}$ (Oinuma and Hayashi 1968, Farmer 1974). Furthermore, a sharp band at about $3673 \mathrm{~cm}^{-1}$ is also common in the spectra of the two minerals and overlapped by the tremolite's band.

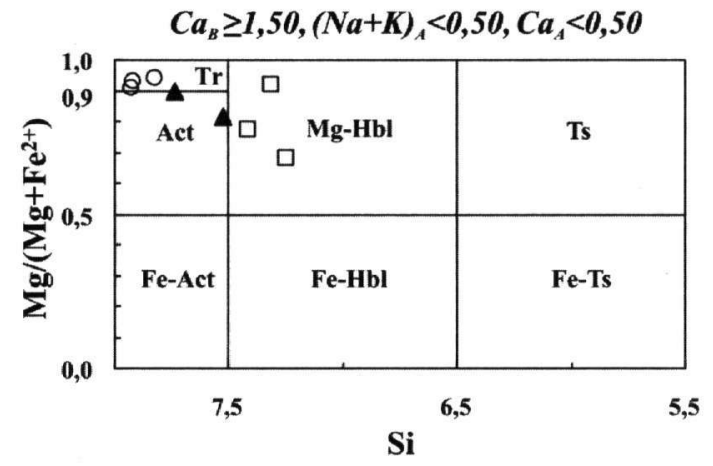

(a)

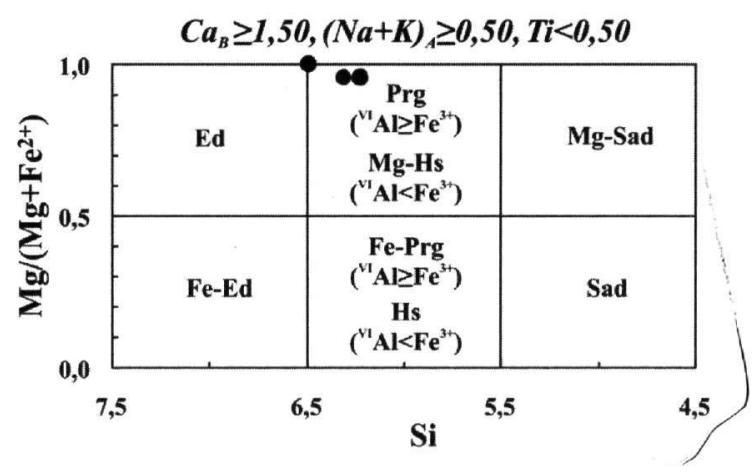

(b)

Figure 2 - Nomenclature diagrams. O - T1, T2, T3, А - A1, A2, $\square-$ H1, H2, H3, - P1, P2, P3). (Tr: tremolite, Act: actinolite, Fe-Act: Fe-actinolite, Mg-Hbl: Mg-hornblende, Fe-Hbl: Fe-hornblende, Ts: tschermakite, Fe-Ts: Fe-tschermakite, Ed: edenite, Fe-Ed: Fe-edenite, Prg: pargasite, Fe-Prg: Fe-pargasite, Mg-Hs: Mg-hastingsite, Hs: hastingsite, Mg-Sad: Mgsadanagaite, Sad: sadanagaite)

\subsection{Pargasites}

\subsubsection{Low frequency region: $400-1600 \mathrm{~cm}^{-1}$}

The spectra of pargasites (Figs 3d, 4d) present the common characteristics of Ca-amphiboles at about $1000 \mathrm{~cm}^{-1}$ and below $600 \mathrm{~cm}^{-1}$ that were mentioned above. In the investigated samples, the presence of a band at $457-464 \mathrm{~cm}^{-1}$ is characteristic of the spectra of natural actinolites (Gopal et al. 2004 ) and is attributed to Si-O bending vibration. Since this bond is common characteristic in all Ca-amphiboles, potentially it can be also related to the $\mathrm{Si}-\mathrm{O}$ bending vibration in pargasites. Prasad et al. (2000) mentioned that the absorption band at $661-668 \mathrm{~cm}^{-1}$ is related with the presence of $\mathrm{Fe}^{2+}$ in the structure of the mineral. The band at $683-687 \mathrm{~cm}^{-1}$ is attributed to symmetrical stretching vibration of $\mathrm{Si}-\mathrm{O}-\mathrm{Si}$ bond (Gopal et al. 2004). Eight more absorption bands (at 981-984, 931, 919, 805-811, 734, 696-698, 507-513 and $419 \mathrm{~cm}^{-1}$ ) are observed in the spectra of the pargasites, but there are no references relating them to specific bond vibrations. 


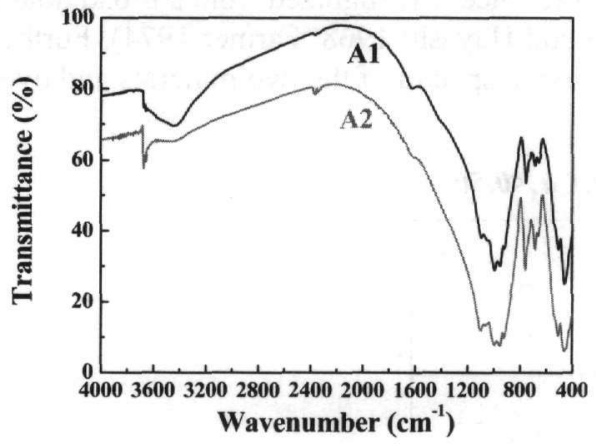

(a)

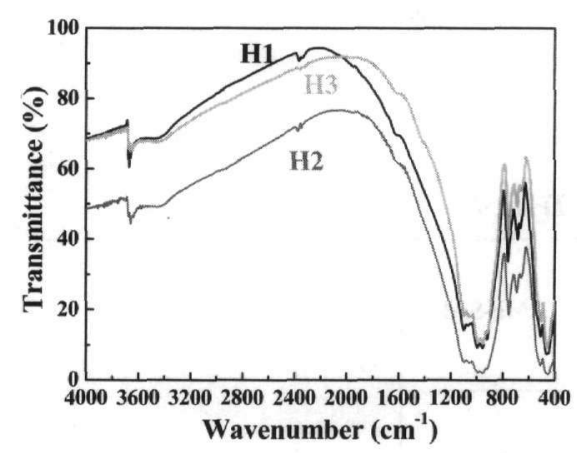

(c)

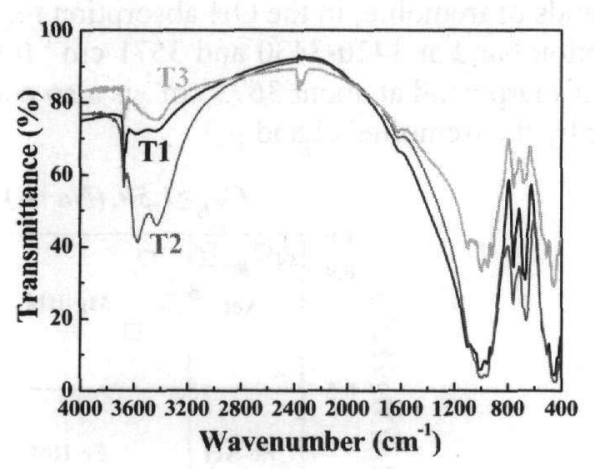

(b)

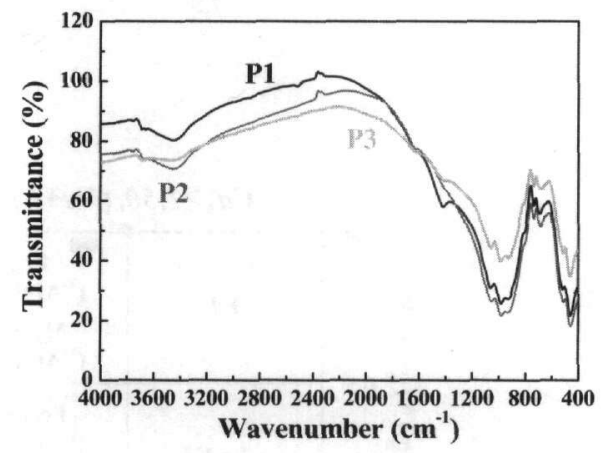

(d)

Figure 3 - FTIR spectra in the region $4000-400 \mathrm{~cm}^{-1}$. Samples as in Table 1

\subsection{2. $\mathrm{OH}$ absorption region}

Della Ventura et al. (2003) reported that the absorption band at about $3690 \mathrm{~cm}^{-1}$ is observed when in the structure of pargasites the M3 and T1 sites are occupied by A1, the M1, M2 and M3 sites by $\mathrm{Mg}$ and the A site by Na. Burns and Strens (1966) and Burns and Greaves (1971) reported a band at $3658 \mathrm{~cm}^{-1}$ attributed to the presence of $\mathrm{Mg}$ in the $\mathrm{M} 1$ sites and $\mathrm{Fe}^{2+}$ in the M3 site in the tremolite-actinolite series. This band is also observed in the spectra of pargasites and it can potentially be attributed to the presence of $\mathrm{Mg}$ in $\mathrm{M} 1$ sites and $\mathrm{Fe}^{2+}$ in $\mathrm{M} 3$ site.

\section{Discussion}

Several key observations have come from the investigation and comparison of the FTIR spectra of the four species of natural Ca-amphiboles.

It is clear that in the spectra of all samples many similarities have been observed in specific wavenumber regions. In these regions absorption bands corresponding to bonds of common elements in the crystal structure of the Ca-amphiboles are observed. Particularly, in all samples there have been observed the same absorption bands at 3658-3660, 983-987, 919, 661-668, 505$513,457-464$ and $419 \mathrm{~cm}^{-1}$. According to Lucania et al. (2002), who claim that in the spectra of natural actinolites there are characteristic bands at $919,683-687,661-668$ and $441-445 \mathrm{~cm}^{-1}$, it is considered that the above four bands are characteristic not only for actinolites, but also for tremolites, $\mathrm{Mg}$-hornblendes and pargasites. This is predictable because all samples belong to the same group, crystallize in the same system (monoclinic) and consist of the same chemical elements. 


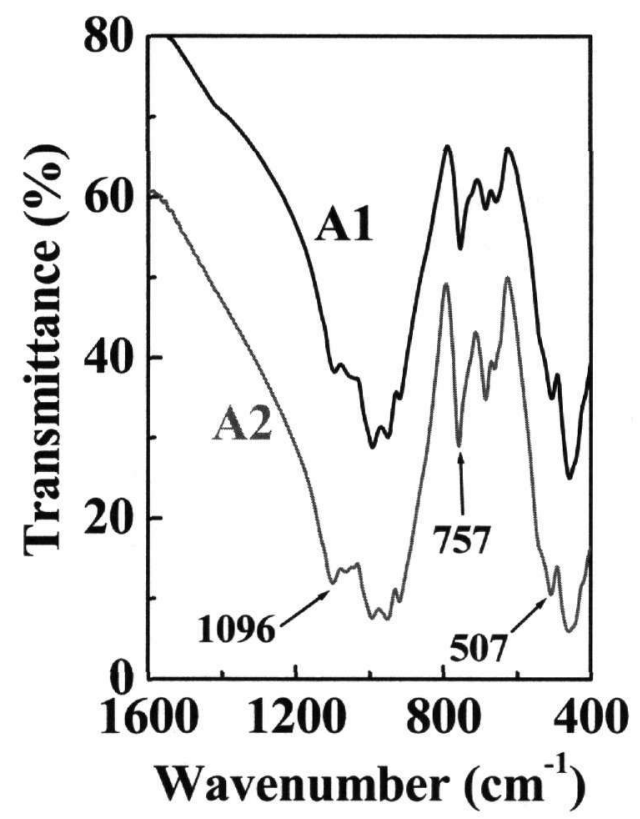

(a)

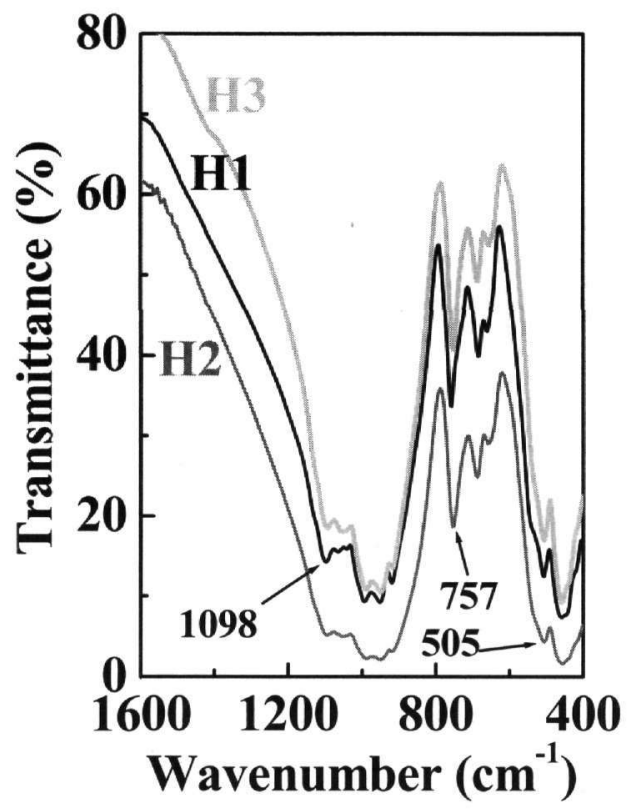

(c)

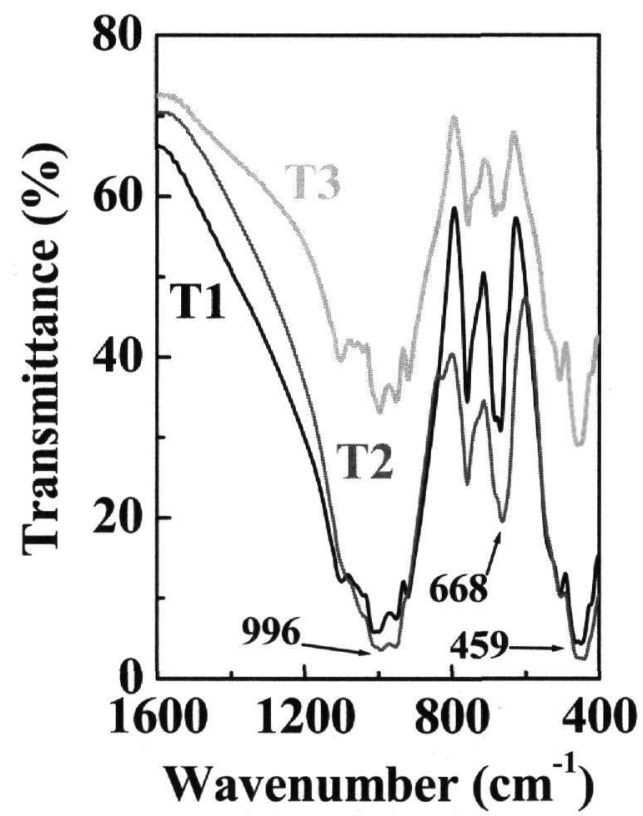

(b)

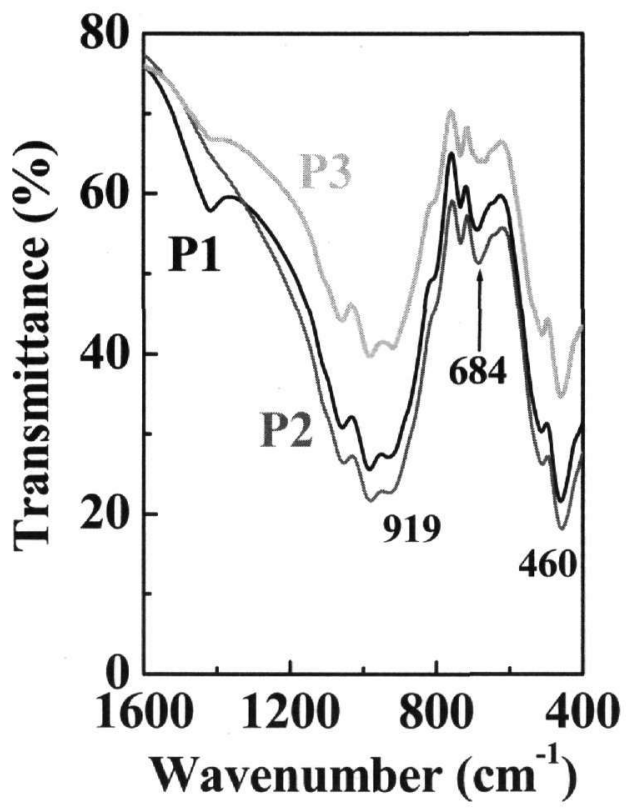

(d)

Figure 4 - FTIR spectra in the region $1600-400 \mathrm{~cm}^{-1}$. Samples as in Table 1 


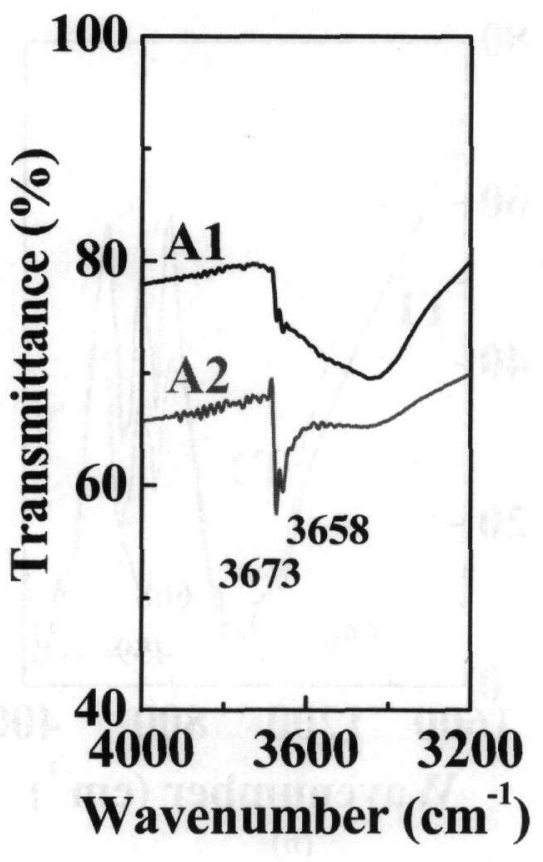

(a)

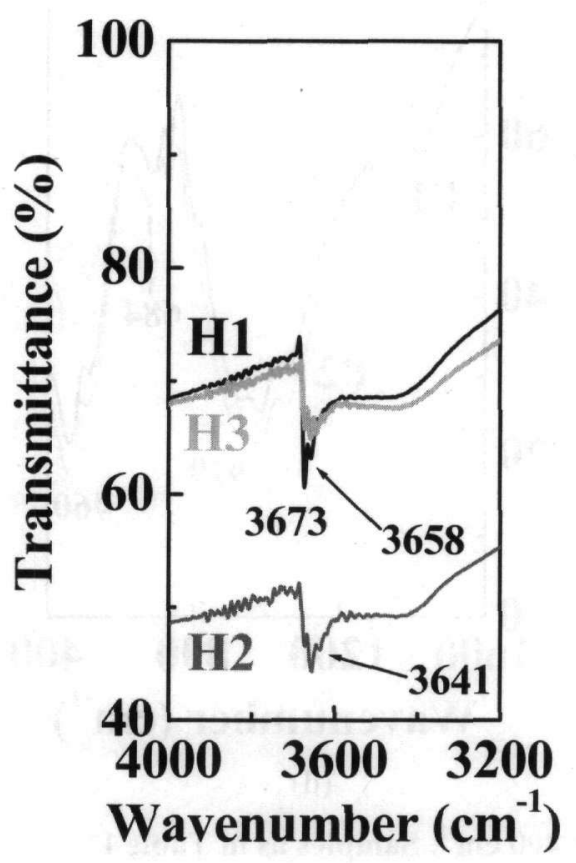

(c)

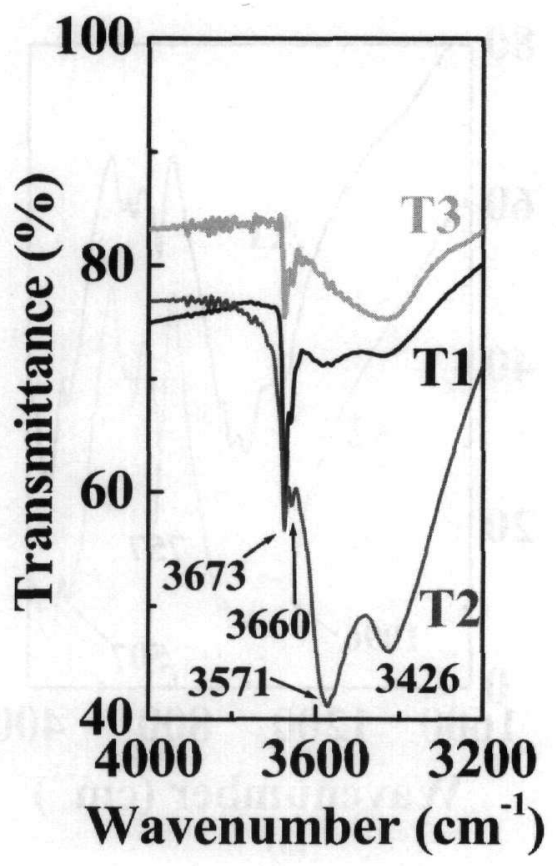

(b)

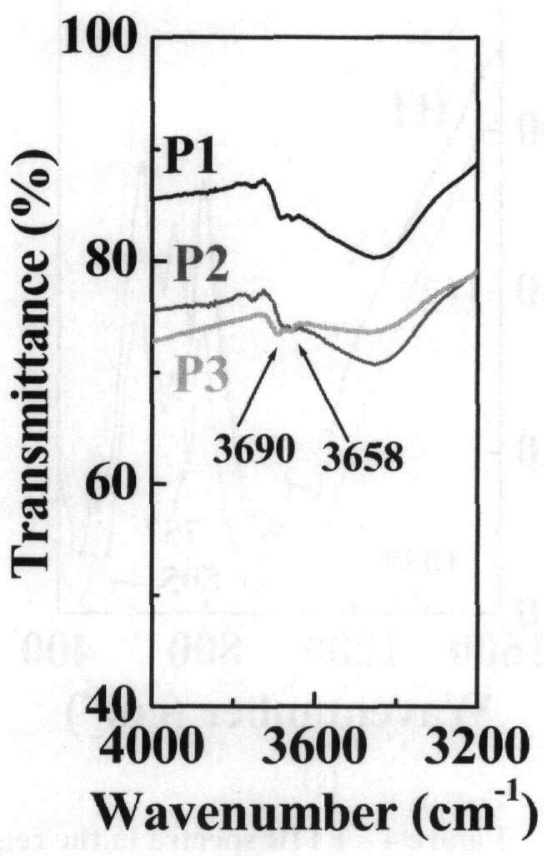

(d)

Figure 5 - FTIR spectra in the region $4000-3200 \mathrm{~cm}^{-1}$. Samples as in Table 1 
In the spectra of actinolites, tremolites and Mg-hornblendes six more absorption bands (at 3673, 1094-1098, 989-998, 951, 752-758 and 441-449 $\mathrm{cm}^{-1}$ ) apart from the common ones are observed. These bands have not been detected in the spectra of pargasites (see below). This arises from the fact that the same sites of the crystal structure of the three species are occupied by the same elements. Although the samples are classified as three different species of Ca-amphiboles, they plot close to the separating lines in the nomenclature diagram (Fig. 2a) and they have only small differences in their chemical composition (Table 2). Also it must be mentioned that the investigated samples are natural crystals and consequently they have lattice defects that disturb the periodicity of the crystal. The elements which are close to a bond they slightly affect it. In the quite complicated amphibole structure, the A site, which is vacant in the ideal chemical formula of actinolites, tremolites and hornblendes (Leake et al. 2003), is partly occupied by $\mathrm{Na}$ and $\mathrm{K}$ in the examined samples (Table 2). The small differences in their chemical composition, the not ideally crystallized structure and the occupancy of the typically vacant sites by cations, change the lengths and the angles among the bonds and affect their vibrational frequency. All these alterations are represented as shifting of the absorption bands in the FTIR spectra and consequently the three species of natural Ca-amphiboles can not be obviously distinguished. A weak absorption band at $3641 \mathrm{~cm}^{-1}$ observed only in the spectra of $\mathrm{H} 2$ and $\mathrm{H} 3$ samples, is due to their higher amount of Fe in their structure than the other samples and can not be characterized as a special feature of $\mathrm{Mg}$ hornblendes' spectra.

In the spectra of pargasites, six absorption bands (at 3690, 981-984, 931, 805-811, 734 and 696$698 \mathrm{~cm}^{-1}$ ), apart from the common ones, are observed, making possible its discrimination from the other three species of Ca-amphiboles. These differences in their spectra are probably due to the A site occupancy, mostly by $\mathrm{Na}$ ions, and the higher concentration of $\mathrm{Al}$ relative to the rest three species. These differences can shift, reveal or even suppress some bands.

\section{Conclusions}

From the study of the FTIR spectra of natural Ca-amphiboles, it can be observed that:

1. The spectra of natural actinolites, tremolites, $\mathrm{Mg}$-hornblendes and pargasites have common absorption bands at $3658-3660 \mathrm{~cm}^{-1}\left(\mathrm{MgMgFe}^{2+}\right.$ in M1M1M3 sites), 683-687 $\mathrm{cm}^{-1}$ (Si-O-Si symmetrical stretching vibration), $661-668 \mathrm{~cm}^{-1}$ (small amount of $\mathrm{Fe}^{2+}$ ), 457-464 $\mathrm{cm}^{-1}$ (Si$\mathrm{O}$ bending vibration), $919,505-513$ and $419 \mathrm{~cm}^{-1}$ (no literature exist concerning these bands).

2. The spectra of natural actinolites, tremolites and Mg-hornblendes have six more absorption bands in addition to the common ones, at $3673 \mathrm{~cm}^{-1}$ (MgMgMg in M1M1M3 sites), 1094$1098 \mathrm{~cm}^{-1}$ (Si-O-Si antisymmetrical stretching vibration), $951 \mathrm{~cm}^{-1}$ (Si-O bending vibration), $752-758 \mathrm{~cm}^{-1}$ (Si-O-Si symmetrical stretching vibration), 989-998 and 441-449 $\mathrm{cm}^{-1}$ (no literature exist concerning these bands). In samples $\mathrm{H} 2$ and $\mathrm{H} 3$ observed an extra band at $3641 \mathrm{~cm}^{-1}\left(\mathrm{MgFe}^{2+} \mathrm{Fe}^{2+}\right.$ in M1M1M3 sites).

3. The spectra of natural pargasites have six more absorption bands in addition to the common ones at $3690 \mathrm{~cm}^{-1}$ (A1 in M3 and T1 sites, Mg in M1, M2 and M3 sites and Na in A site), 981-984, 931, 805-811, 734 and 696-698 $\mathrm{cm}^{-1}$ (no literature exist concerning these bands). These bands are not present in the spectra of the other three species, hence they can be used to discriminate them.

Therefore, it can be concluded that FTIR method seems to be capable in discriminating pargasites from the rest $\mathrm{Ca}$-amphiboles.

\section{Acknowledgments}

We gratefully acknowledge the contribution of Dr Fabio Bellatreccia and an anonymous reviewer for their very constructive reviews, improving the quality of the paper. 


\section{References}

Burns, R. G., and Greaves, C. J., 1971. Correlations of infrared and Mössbauer site-population measurements of actinolites. Am. Mineral., 56, 2010-2033.

Burns, R. G., and Strens, R. G. J., 1966. Infrared study of the hydroxyl bands in clinoamphiboles, Science, $153,890-892$.

Carmichael, R. S., 1982. Handbook of physical properties of rocks, vol. II., CRC Press, Florida.

Christofides, G., 1977. Contribution to the study of the plutonic rocks of Xanthi area, $P h D$ Thesis, Aristotle University of Thessaloniki, 249pp.

Della Ventura, G., Hawthorne, F. C., Robert, J.-L., and Iezzi, G., 2003. Synthesis and infrared spectroscopy of amphiboles along the tremolite-pargasite join, Eur. J. Mineral., 15, 341347.

Della Ventura, G., Hawthorne, F. C., Robert, J.-L., Delbove, F., Welch, M.. D., and Raudsepp, M.,1999. Short-range order of cations in synthetic amphiboles along the richterite-pargasite join, Eur. J. Mineral., 11, 79-94.

Farmer, V. C., 1974. The infra-red spectra of minerals, Mineralogical Society, London, 539pp.

Gopal, N. O., Narasimhulu, K. V., and Rao, J. L., 2004. EPR, optical, infrared and Raman spectral studies of actinolite mineral, Spectrochim. Acta, 60A, 2441-2448.

Hawthorne, F. C., 1981. Crystal chemistry of the amphiboles. In D. R. Veblen (ed.), Amphiboles and other hydrous pyriboles - Mineralogy. 1-102, Reviews in Mineralogy, MSA, 9A, 372pp.

Hawthorne, F. C., Welch, M., D., Della Ventura, G., Robert, J.-L., and Jenkins, D. M., 2000. Short-range order in synthetic aluminous tremolites: an infrared and triple-quantum MAS NMR study, Am. Mineral., 85, 1716-1724.

Jenkins, D. M., Bozhilov, K. M., and Ishida, K., 2003. Infrared and TEM characterizationof amphiboles synthesized near the tremolite-pargasite join in the ternary system tremolitepargasite-cummingtonite, Am. Mineral., 88, 1104-1114.

Leake, B. E., Wooley, A. R., Arps, C. E. S., Birch, W. D., Gilbert, M. C., Grice, J. D., Hawthorne, F. C., Kato, A., Kisch, H. J., Krivovichev, V. G., Linthout, K., Laird, J., Mandarino, J. A., Maresh, W. V., Nickel, E. H., Rock, N. M. S., Schumacher, J. C., Smith, D. C., Stephenson, N, C., N., Ungaretti, L., Whittaker, E. J. W., and Youzhi, G., 1997. Nomenclature of Amphiboles: Report of the Subcommittee on Amphiboles of the International Mineralogical Association, Commission on New Minerals and Mineral Names. Canadian Mineral., 35, 219-246.

Leake, B. E., Woolley, A. R., Birch, W. D., Burke, E. A. J., Ferraris, G., Grice, J. D., Hawthorne, F. C., Kisch, H. J., Krivovichev, V. G., Schumacher, J. C., Stephenson, N. C. N., and Whittaker, E. J. W., 2003. Nomenclature of amphiboles: Additions and revisions to the International Mineralogical Association's 1997 recommendations, Canadian Mineral., 41, $1355-1362$.

Lucania, J. P., Berets, S. L., Milosevic, M., Gremlich, H.-U., and Schmitt, J., 2002. The identification of geological samples using single reflection diamond ATR FTIR spectroscopy, Paper 2079P, Pittsburgh Conference.

Oinuma, K., and Hayashi, H., 1968. Infrared spectra of clay minerals, J. Tokyo Univ., Gen. Educ. (Nat. Sci.), 9, 57-98. 
Prasad, P. S. R., Sarma, L. P., Gowd, T. N., and Krishnamurthy, A. S. R., 2000. Structural modifycations in natural tremolites: Spectroscopic studies, Current Science, 78, 729-734. 